\title{
Natural Radioactivity and Dose Assessment for Brands of Chemical and Organic Fertilizers Used in Saudi Arabia
}

\author{
W. R. Alharbi \\ Physics Department, Faculty Science for Girls, king Abdulaziz University, Jeddah, KSA \\ Email: Walhrbi@kau.edu.sa
}

Received November 20, 2012; revised December 29, 2012; accepted January 20, 2013

\begin{abstract}
The activity concentration of naturally occurring radionuclides ${ }^{40} \mathrm{~K},{ }^{226} \mathrm{Ra}$ and ${ }^{232} \mathrm{Th}$ have been measured in different brands of fertilizer samples in Saudi Arabia using sodium iodide gamma spectrometry. The results of measurements showed that the mean (ranges) of specific activities for ${ }^{226} \mathrm{Ra},{ }^{232} \mathrm{Th}$ and ${ }^{40} \mathrm{~K}$ activities in the nitrogen, phosphorus and potassium fertilizers are $64(35.8$ - 120.7), $17(3.2$ - 56.8) and $2453(744.9-4227.1) \mathrm{Bq} / \mathrm{kg}$, respectively. With respect to organic fertilizers under investigation, the average radioactivity of ${ }^{226} \mathrm{Ra},{ }^{232} \mathrm{Th}$ and ${ }^{40} \mathrm{~K}$ are 42,10 and $333 \mathrm{BqKg}^{-1}$, respectively. Radium equivalent activity is not exceed $370 \mathrm{~Bq} / \mathrm{kg}$, the maximum permissible limit for radiation dose for all present samples. Average values of the three natural radionuclides measured in the brands of fertilizers used in Saudi Arabia are within the range of values reported in several other countries. This study could be useful as baseline data for radiation exposure to fertilizers and their impact on human health.
\end{abstract}

Keywords: Chemical Fertilizers; Organic Fertilizer; Environmental Radioactivity

\section{Introduction}

In order to reach high agricultural productivity, the present practice of replacing nutrients in soils and consequently supplying substances is done by the application of chemical fertilizers, mostly compounds commercially named NPK (nitrogen $(\mathrm{N})$, phosphorus $(\mathrm{P})$ and potassium $(\mathrm{K})$ ) and NPKs (sulfate based fertilizer), the phosphorus portion is taken from phosphate rocks, which contain enhanced concentration of natural radionuclides, [1,2]. So, fertilizers redistribute naturally occurring radionuclides at trace levels throughout the environment and become a source of radioactivity, this phenomenon may result in potential radiological risks owing to external exposure during resident time in the farms and internal exposure through ingestion of food grown on fertilizer soils, [3]. The use of different types of fertilizers in the agricultural sector for the purpose of enhancing crop yield has become very common nowadays, fertilizers are usually used in reclaiming the land and improving the properties of crops. Many types of fertilizers are used in Saudi Arabia like: Super Phosphate, Urea Sulfate, and Ammonium Nitrate Sulfate. Using phosphate fertilizers over a period of many years could eventually increase the radium and uranium content of the soil and consequently increase the radiation dose which would result in the corresponding increase of the dose and causes diseases for human body, [4]. Also, during handling, packing and transporting fer- tilizers, some workers can receive additional external exposure at dose rates up to $0.8 \mathrm{mGy} \cdot \mathrm{h}^{-1}[5]$. So it is important to measure natural radioactivity in fertilizers and by-products, because the high radioactive content may lead to significant exposure of miners, manufacturers and end users. Furthermore, such measurements provide basic data for the estimation of the amount of radioactivity spread on agricultural land along with fertilizers.

Worldwide, several studies have been carried out in the vicinities of phosphate fertilizer industries [4,6-8]. All the studies mentioned, and others, have assessed the radioactive pollution caused by production plants on the human population. The main pathways of human exposure have been published by [9].

The aim of the present study is to: 1) determine the activity concentrations of naturally occurring radionuclides in a famous fertilizer samples of different brands of NPK fertilizer and organic fertilizers, which are available samples in Saudi markets, 2) provide a useful information in the monitoring of environmental contamination by natural radioactivity.

\section{Materials and Method}

Forty five samples of 9 different brands were collected from the local market of Al-Taif City, 30 samples chemical and 15 samples an organic fertilizers. The code type and other information about these samples are sum- 
marized in Table 1. All the brands of fertilizer are solid. After collection, the samples were ground, pulverized to fine powdered material, heated in the oven at $80^{\circ} \mathrm{C}$ for 24 $\mathrm{h}$ to remove moisture and then sealed in plastic containers to avoid any possibility of out gassing of radon. The samples were left a side for a month to allow the attainment of ${ }^{226} \mathrm{Ra}-{ }^{222} \mathrm{Rn}$ Radioactive equilibrium. The activity concentrations of ${ }^{226} \mathrm{Ra},{ }^{232} \mathrm{Th}$ and ${ }^{40} \mathrm{~K}$ for all equilibrium samples were measured by a gamma ray spectrometry using a NaI (TI) detector $3 \times 3$ inch with a 1024channel computer analyzer. The detector has a peak efficiency of $1.2 \times 10^{-5}$ at $1332.5 \mathrm{keV}$ Co-60 and an energy resolution (FWHM) of $7.5 \%$ for $662 \mathrm{keV}$, detector employed with adequate lead shielding which reduces the background radiation.

\section{Theoretical Calculations}

\subsection{Calculation the Activity Concentrations}

The specific activity of ${ }^{226} \mathrm{Ra}$ was evaluated from gamma-ray lines of ${ }^{214} \mathrm{Bi}$ at $609.3 \mathrm{keV}$ and ${ }^{214} \mathrm{~Pb}$ at $351.9 \mathrm{keV}$, while the specific activity of ${ }^{232} \mathrm{Th}$ was evaluated from gamma-ray lines of ${ }^{212} \mathrm{~Pb}$ at $238.6 \mathrm{keV},{ }^{228} \mathrm{Ac}$ at 911.1 $\mathrm{keV}$. The specific activity of ${ }^{40} \mathrm{~K}$ was determined directly from its $1460.8 \mathrm{keV}$ gamma-ray line. Activity calculations have been carried out using the procedure given by [10] the activity concentrations in each sample were evaluated using the following relation $[11,12]$ :

$$
A_{S}\left(\mathrm{~Bq} \cdot \mathrm{kg}^{-1}\right)=C_{a} / \varepsilon P_{r} M_{s}
$$

where $C_{a}$ is the net gamma counting rate (counts per second), $\varepsilon$ the detector efficiency of the specific $\gamma$-ray, $P_{r}$ the absolute transition probability of Gamma-decay and $M_{s}$ the mass of the sample $(\mathrm{kg})$.

\subsection{Radium Equivalent Activity (Bq/kg)}

To assess the real activity level of ${ }^{226} \mathrm{Ra},{ }^{232} \mathrm{Th}$ and ${ }^{40} \mathrm{~K}$ in fertilizer, a common radiological index has been defined in terms of radium equivalent activity $\left(\mathrm{Ra}_{\mathrm{eq}}\right)$ in $\mathrm{Bq} \cdot \mathrm{kg}^{-1}$ can be used, provides a very useful guideline in regulating the safety standards in radiation protection for a human population. The index was calculated through the following formula is based on the assumption that 370 $\mathrm{Bq} \cdot \mathrm{kg}^{-1}$ of ${ }^{226} \mathrm{Ra},{ }^{259} \mathrm{~Bq} \cdot \mathrm{kg}^{-1}$ of ${ }^{232} \mathrm{Th}$ and $481 \mathrm{~Bq} \cdot \mathrm{kg}^{-1}$ of ${ }^{40} \mathrm{~K}$ produce the same gamma-ray dose rate [13]:

$$
\mathrm{Ra}_{\text {eq }}\left(\mathrm{Bq} \cdot \mathrm{kg}^{-1}\right)=C_{\mathrm{Ra}}+1.43 C_{\mathrm{Th}}+0.077 C_{\mathrm{K}}
$$

where $C_{\mathrm{Ra}}, C_{\mathrm{Th}}$ and $C_{\mathrm{K}}$ are the specific activities $(\mathrm{Bq} / \mathrm{kg}$ dry weight) of ${ }^{226} \mathrm{Ra},{ }^{232} \mathrm{Th}$ and ${ }^{40} \mathrm{~K}$, respectively.

\subsection{Absorbed and Effective Dose}

The measured activity of ${ }^{226} \mathrm{Ra},{ }^{232} \mathrm{Th}$ and ${ }^{40} \mathrm{~K}$ were converted into doses $\left(\mathrm{nGy} \cdot \mathrm{h}^{-1} \mathrm{~Bq}^{-1} \cdot \mathrm{kg}^{-1}\right)$ by applying the
Table 1. Some information of the collected fertilizer samples.

\begin{tabular}{cc}
\hline Sample code & Composition \\
\hline F1 & $20 \mathrm{~N}-20 \mathrm{P}-20 \mathrm{~K}$ \\
F2 & $12 \mathrm{~N}-10 \mathrm{P}-10 \mathrm{~K}$ \\
F3 & $12 \mathrm{~N}-12 \mathrm{P}+2 \mathrm{MgO}+6 \mathrm{~S}$ \\
F4 & $14 \mathrm{~N}-12 \mathrm{P}-14 \mathrm{~K}$ \\
F5 & $15 \mathrm{~N}-30 \mathrm{P}-15 \mathrm{~K}$ \\
F6 & $20 \mathrm{~N}-20 \mathrm{P}-20 \mathrm{~K}$ \\
F7 & Sheep fertilizer \\
F8 & Cow fertilizer \\
F9 & Natural organic \\
\hline
\end{tabular}

factors $0.462,0.604$ and 0.0417 for radium, thorium and potassium, respectively, [14]. These factors were used to calculate the total absorbed gamma dose rate in air at $1 \mathrm{~m}$ above the ground level using the following equation:

$$
\begin{aligned}
& \text { Absorbed dose } D\left(\mathrm{nGy} \cdot \mathrm{h}^{-1}\right) \\
& =0.462 C_{\mathrm{Ra}}+0.604 C_{\mathrm{Th}}+0.0417 C_{\mathrm{K}}
\end{aligned}
$$

where $C_{\mathrm{Ra}}, C_{\mathrm{Th}}$ and $C_{\mathrm{K}}$ are the activities $\left(\mathrm{Bq} \cdot \mathrm{kg}^{-1}\right)$ of radium, thorium and potassium in the samples. To estimate annual effective doses, must be taken into account of 1) the conversion coefficient from absorbed dose in air to effective dose and 2) the indoor occupancy factor. The annual effective doses are determined as follows [14]:

$$
\begin{aligned}
& \text { Outdoor annual effective dose }(\mathrm{mSv}) \\
& =D\left(\mathrm{nGy} \cdot \mathrm{h}^{-1}\right) \times 8760 \mathrm{~h} \times 0.2 \times 0.7 \mathrm{~Sv} \cdot \mathrm{Gy}^{-1} \times 10^{-6}
\end{aligned}
$$

Annual estimated average effective dose equivalent received by a member is calculated using a conversion factor of $0.7 \mathrm{~Sv} \cdot \mathrm{Gy}^{-1}$, which is used to convert the absorbed rate to annual effective dose with an outdoor occupancy of $20 \%$ [15].

\section{Results and Discussion}

The measured concentrations of natural radionuclides ${ }^{226} \mathrm{Ra},{ }^{232} \mathrm{Th}$ and ${ }^{40} \mathrm{~K}$ in fertilizer samples are shown in Table 2. In chemical fertilizers, the concentration of ${ }^{226} \mathrm{Ra}$ varies from 35.8 to $120.7 \mathrm{~Bq} \cdot \mathrm{kg}^{-1}$ with an average value of $64 \mathrm{~Bq} \cdot \mathrm{kg}^{-1}$, the concentration of ${ }^{232} \mathrm{Th}$ varies from 3.2 to $56.8 \mathrm{~Bq} \cdot \mathrm{kg}^{-1}$ with an average value of 17 $\mathrm{Bq} \cdot \mathrm{kg}^{-1}$, whereas the concentration of ${ }^{40} \mathrm{~K}$ exists in the range from $744.9-4227.1 \mathrm{~Bq} \cdot \mathrm{kg}^{-1}$ with an average value of $2453 \mathrm{~Bq} \cdot \mathrm{kg}^{-1}$. For the organic fertilizer, the average activity of ${ }^{226} \mathrm{Ra},{ }^{232} \mathrm{Th}$ and ${ }^{40} \mathrm{~K}$ are 42,10 and 333 $\mathrm{Bq} \cdot \mathrm{kg}^{-1}$, respectively. The results showed that the chemical fertilizers have the highest emitter of the radiation in 
Table 2. The activity concentrations of ${ }^{226} \mathrm{Ra},{ }^{232} \mathrm{Th}$ and ${ }^{40} \mathrm{~K}$ $(\mathrm{Bq} / \mathrm{Kg})$ in chemical and organic fertilizers.

\begin{tabular}{|c|c|c|c|}
\hline \multirow{2}{*}{$\begin{array}{l}\text { Fertilizer } \\
\text { type }\end{array}$} & \multicolumn{3}{|c|}{ Activity concentration $(\mathrm{Bq} / \mathrm{Kg})$} \\
\hline & ${ }^{226} \mathrm{Ra}$ & ${ }^{232} \mathrm{Th}$ & ${ }^{40} \mathrm{~K}$ \\
\hline F1 & $\begin{array}{c}(29.3-67.3) \\
45.7 \pm 2\end{array}$ & $\begin{array}{c}(8.58-27.58) \\
16.5 \pm 7\end{array}$ & $\begin{array}{c}(1167.3-227.3) \\
2373.2 \pm 18\end{array}$ \\
\hline $\mathrm{F} 2$ & $\begin{array}{c}(45.5-87.9) \\
63.4 \pm 8\end{array}$ & $\begin{array}{c}(6.5-11.12) \\
9.6 \pm 0.5\end{array}$ & $\begin{array}{c}(788.5-2502.9) \\
2010.5 \pm 23\end{array}$ \\
\hline F3 & $\begin{array}{c}(35.8-81.1) \\
62.9 \pm 8\end{array}$ & $\begin{array}{c}(11.51-56.81) \\
29.1 \pm 3\end{array}$ & $\begin{array}{c}(2138.1-4227.2) \\
3076 \pm 37\end{array}$ \\
\hline F4 & $\begin{array}{c}(45.5-75) \\
58.6 \pm 7\end{array}$ & $\begin{array}{c}(8.35-19.48) \\
15.2 \pm 0.4\end{array}$ & $\begin{array}{c}(749.9-4127.1) \\
3065.7 \pm 43\end{array}$ \\
\hline F5 & $\begin{array}{c}(46.4-85.2) \\
66.4 \pm 8\end{array}$ & $\begin{array}{c}(12.21-37.72) \\
22.9 \pm 2\end{array}$ & $\begin{array}{c}(754.6-3175.8) \\
2155.2 \pm 22\end{array}$ \\
\hline F6 & $\begin{array}{c}(54.9-120.7) \\
83.9 \pm 11\end{array}$ & $\begin{array}{c}(3.16-14.47) \\
9.2 \pm 0.4\end{array}$ & $\begin{array}{c}(1048.8-2959.1) \\
2038.3 \pm 35\end{array}$ \\
\hline $\begin{array}{l}\text { Average } \\
\text { Value }\end{array}$ & 64 & 17 & 2453 \\
\hline F7 & $\begin{array}{l}(21-45.3) \\
31.6 \pm 1.6\end{array}$ & $\begin{array}{c}(3.2-9.8) \\
6.3 \pm 0.3\end{array}$ & $\begin{array}{c}(115.2-396.3) \\
277.3 \pm 12\end{array}$ \\
\hline F8 & $\begin{array}{c}(25.8-48.6) \\
41.1 \pm 1.7\end{array}$ & $\begin{array}{c}(4.77-11.36) \\
7.5 \pm 0.3\end{array}$ & $\begin{array}{c}(135.4-523.8) \\
284.5 \pm 8\end{array}$ \\
\hline F9 & $\begin{array}{c}(45.7-70.3) \\
54.2 \pm 1.3\end{array}$ & $\begin{array}{c}(4.95-21.31) \\
16.9 \pm 3\end{array}$ & $\begin{array}{c}(135.4-523.8) \\
410.7 \pm 14\end{array}$ \\
\hline $\begin{array}{l}\text { Average } \\
\text { value }\end{array}$ & 42 & 10 & 333 \\
\hline
\end{tabular}

comparison with the organic samples under study.

Table 3, presents, the range value of radium equivalent activity $\left(\mathrm{Ra}_{\mathrm{eq}}\right)$ for chemical fertilizers varied from 224.9 to $349.7 \mathrm{~Bq} \cdot \mathrm{kg}^{-1}$ with an average value 275 $\mathrm{Bq} \cdot \mathrm{kg}^{-1}$, and for organic the average value $77 \mathrm{~Bq} \cdot \mathrm{kg}^{-1}$, therefor, the radium equivalent activity is not exceed 370 $\mathrm{Bq} / \mathrm{kg}$, the maximum permissible limit for radiation dose for all samples. So, the results of this study will contribute to the national data regarding natural radioactivity levels in fertilizers used in Saudi Arabia.

The absorbed and annual effective dose rates from the samples were calculated as shown in Table 3. The minimum and maximum values of absorbed dose and outdoor annual effective dose in the chemical samples studied in the present work, were found to vary from $118 \mathrm{nGy} \cdot \mathrm{h}^{-1}$ to $155 \mathrm{nGy} \cdot \mathrm{h}^{-1}$ with an average value $126 \mathrm{nGy} / \mathrm{h}$, and $0.13 \mathrm{mSvy}^{-1}$ to $0.19 \mathrm{mSvy}^{-1}$ with an average value 0.15 $\mathrm{mSvy}^{-1}$, respectively. For organic fertilizer the maximum value is $77.2 \mathrm{nGy} \cdot \mathrm{h}^{-1}$ and the minimum is $40.8 \mathrm{nGy} \cdot \mathrm{h}^{-1}$ with an average value is $57 \mathrm{nGy} \cdot \mathrm{h}^{-1}$. The larger value given for the absorbed dose rate is of $55 \mathrm{nGy} / \mathrm{h}(24-85$ $\mathrm{nGy} / \mathrm{h},[16]$. A more recent UNSCEAR report gave wide range (18 - $93 \mathrm{nGy} / \mathrm{h})$ with an average value of $59 \mathrm{nGy} / \mathrm{h}$, [14]. The results showed that absorbed dose rate for the chemical fertilizer samples are higher than the world li-
Table 3. Radium equivalent, absorbed dose and dose equivalent for different samples.

\begin{tabular}{cccc}
\hline $\begin{array}{c}\text { Sample of } \\
\text { fertilizer }\end{array}$ & $\mathrm{Ra}_{\text {eq }}(\mathrm{Bq} / \mathrm{Kg})$ & $\begin{array}{c}\text { Absorbed dose } \\
\left(\mathrm{nGy} \cdot \mathrm{h}^{-1}\right)\end{array}$ & $\begin{array}{c}\text { Outdoor } \\
(\mathrm{mSv})\end{array}$ \\
\hline F1 & 257.5 & 118 & 0.15 \\
F2 & 240.6 & 103.7 & 0.13 \\
F3 & 349.7 & 155.3 & 0.19 \\
F4 & 332.8 & 155.8 & 0.19 \\
F5 & 245.2 & 118.7 & 0.15 \\
F6 & 224.9 & 104.2 & 0.13 \\
$\begin{array}{c}\text { Average values } \\
\text { (chemical fertilizers) }\end{array}$ & 275 & 126 & 0.15 \\
F7 & 40.8 & 28.6 & 0.03 \\
F8 & 52.3 & 35.3 & 0.04 \\
F9 & 77.2 & 51 & 0.06 \\
Average values & 57 & 38 & 0.04 \\
\hline (organic fertilizers) & 57 & &
\end{tabular}

mits, but the effective dose rates for all samples were not exceed the recommended value $1 \mathrm{mSv}$. Therefore, all the samples analyzed in the present work satisfy the safety criterion for general public [17]. Hence, most of these samples do not pose much health hazard for the population.

Figures 1 and 2, describe the average activity of ${ }^{226} \mathrm{Ra}$, ${ }^{232} \mathrm{Th},{ }^{40} \mathrm{~K}\left(\mathrm{~Bq} \cdot \mathrm{Kg}^{-1}\right)$ and the radium equivalent with absorbed dose of different fertilizer used in Saudi Arabia, respectively. Table 4 shows average concentrations of the radionuclides in our study compared with the reported values from other countries. It is found that for NPK fertilizers the average ${ }^{226} \mathrm{Ra}$ concentration of (64 $\mathrm{Bqkg}^{-1}$ ) is the lowest activity concentration values in comparison with other reported values concentrations except that of Finland $\left(54 \mathrm{~Bq} \cdot \mathrm{kg}^{-1}\right)$.

The average ${ }^{232} \mathrm{Th}$ concentration of $\left(17 \mathrm{~Bq} \cdot \mathrm{kg}^{-1}\right)$ is found lower than the reported concentration from Egypt $\left(67 \mathrm{~Bq} \cdot \mathrm{kg}^{-1}\right)$, India $\left(28 \mathrm{~Bq} \cdot \mathrm{kg}^{-1}\right)$, USA $\left(49 \mathrm{~Bq} \cdot \mathrm{kg}^{-1}\right)$ and Brazil $\left(80 \mathrm{~Bq} \cdot \mathrm{kg}^{-1}\right)$, but it is higher than the reported concentrations from Saudi Arabia-Reyadh $\left(23 \mathrm{~Bq} \cdot \mathrm{kg}^{-1}\right)$, Finland $\left(11 \mathrm{~Bq} \cdot \mathrm{kg}^{-1}\right)$ and Germany $\left(15 \mathrm{~Bq} \cdot \mathrm{kg}^{-1}\right)$. The average ${ }^{40} \mathrm{~K}$ concentration of $\left(2453 \mathrm{~Bq} \cdot \mathrm{kg}^{-1}\right)$ is lower than the values reported concentrations from Finland (3200 Bq. $\left.\mathrm{kg}^{-1}\right)$ and Nigeria $\left(2729 \mathrm{~Bq} \cdot \mathrm{kg}^{-1}\right)$ and higher than the other values under comparison.

\section{Conclusion}

Concentrations of ${ }^{226} \mathrm{Ra},{ }^{232} \mathrm{Th}$ and ${ }^{40} \mathrm{~K}$ in thirty five fertilizer samples collected from Al-Taif city (Saudi Arabia) have been measured using gamma spectrometry. Average 
Table 4. Comparison of activity concentrations of ${ }^{40} \mathrm{~K},{ }^{226} \mathrm{Ra}$ and ${ }^{232} \mathrm{Th}$ in Saudi Arabian samples and other countries.

\begin{tabular}{|c|c|c|c|c|c|c|}
\hline \multirow{2}{*}{ Country } & \multirow{2}{*}{ Sample } & \multicolumn{3}{|c|}{ Activity Concentrations (Bq/Kg) } & \multirow{2}{*}{$\mathrm{Ra}_{\mathrm{eq}}(\mathrm{Bq} / \mathrm{Kg})$} & \multirow{2}{*}{ Reference } \\
\hline & & ${ }^{226} \mathrm{Ra}$ & ${ }^{232} \mathrm{Th}$ & ${ }^{40} \mathrm{~K}$ & & \\
\hline Egypt & NPK & 366 & 67 & 4 & 462 & [18] \\
\hline India & NPK & 79 & 28 & 1024 & 198 & [19] \\
\hline Germany & NPK & 520 & 15 & 720 & 597 & [20] \\
\hline Nigeria & NPK & 143 & 9 & 2729 & 366 & [21] \\
\hline Brazil & NPK & 420 & 80 & 153 & 546 & [22] \\
\hline Finland & NPK & 54 & 11 & 3200 & 316 & [23] \\
\hline USA & NPK & 780 & 49 & 200 & 865 & [24] \\
\hline Saudi Arabia (Riyadh) & NPK & 75 & 23 & 2059 & 266 & {$[6]$} \\
\hline Saudi Arabia & NPK & 64 & 17 & 2453 & 275 & Present work \\
\hline
\end{tabular}

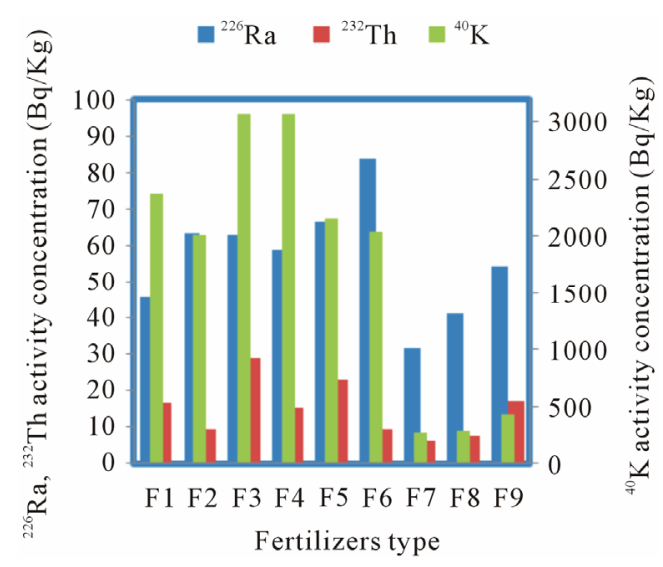

Figure 1. Average activity concentrations of ${ }^{226} \mathrm{Ra},{ }^{232} \mathrm{Th}$ and ${ }^{40} \mathrm{~K}(\mathrm{~Bq} / \mathrm{Kg})$ of different fertilizer type from Saudi Arabia.

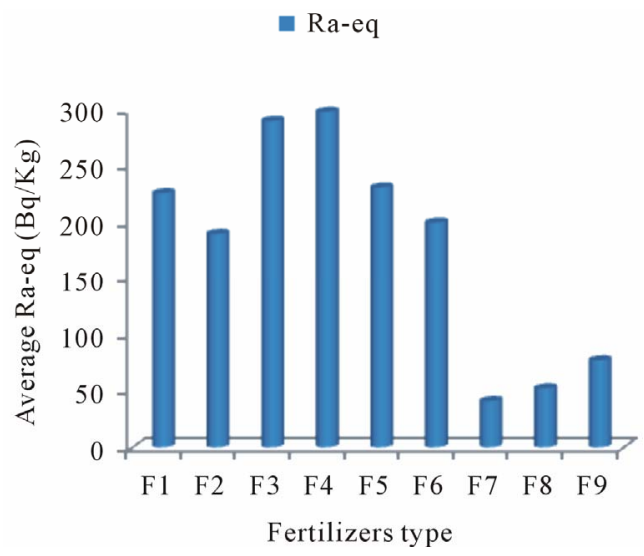

Figure 2. Average radium equivalent $(\mathrm{Bq} / \mathrm{Kg})$ in chemical and organic fertilizers used in Saudi Arabia.

concentrations of ${ }^{226} \mathrm{Ra},{ }^{232} \mathrm{Th}$ and ${ }^{40} \mathrm{~K}$ are 64,17 and $2453 \mathrm{~Bq} \cdot \mathrm{kg}^{-1}$, respectively. These values have been compared with the world wide reported data. The result showed that the highest values presented in chemical fertilizers and the lowest values were found in the organic fertilizers. Radium equivalent activity for all present samples were below the recommended limits $(370$ $\left.\mathrm{Bq} \cdot \mathrm{kg}^{-1}\right)$. The obtained results are in good agreement with those determined for Riyadh samples. From the calculated value it is recommended to use organic Fertilizer rather than chemicals.

\section{REFERENCES}

[1] E. M. K. Ashraf, R. H. Higgy and M. Pimpl, "Radiological Impacts of Natural Radioactivity in Abu-Taror Phosphate Deposits Egypt," Journal of Environmental Radioactivity, Vol. 55, No. 3, 2001, pp. 255-267. doi:10.1016/S0265-931X(00)00193-4

[2] J. I. Skorovarov, L. I. Rusin, A. V. Lomonsov, H. Chaforian, A. Hashemi and H. Novaseqhi, "Development of Uranium Extraction Technology from Phosphoric Acid Solutions with Extract," Proceeding of International Conference on Uranium Extraction from Soil, Vol. 217, 2000, pp. 106-113.

[3] S. Rehman, N. Imtiaz, M. Faheem and Matiullah, "Determination of $238 \mathrm{U}$ Contentsin Ore Samples Using CR39 Based Radon Dosimeter Disequilibrium Case," Radiation Measurements, Vol. 41, 2006, pp. e471-e476.

[4] S. Righi, P. Lucialli and L. Bruzzi, "Health and Environmental Impacts of a Fertilizer Plant Part I: Assessment of Radioactive Pollution," Journal of Environmental Radioactivity, Vol. 82, No. 2, 2005, pp. 167-182. doi:10.1016/j.jenvrad.2004.11.007

[5] A. G. E. Abbady, M. A. M. Uosif and A. El-Taher, "Natural Radioactivity and Dose Assessment for Phosphate Rocks from Wadi El-Mashash and El-Mahamid Mines, Egypt," Journal of Environmental Radioactivity, Vol. 84, No. 1, 2005, pp. 65-78. doi:10.1016/i.jenvrad.2005.04.003

[6] E. M. Ashraf, Khater and H. A. AL-Sewaidan, "Radiation 
Exposure Due to Agricultural Uses of Phosphate Fertilizers," Radiation Measurements, Vol. 43, No. 8, 2008, pp. 1402-1407. doi:10.1016/j.radmeas.2008.04.084

[7] N. C. Silva, E. Fernandes, M. Cipriani and M. Taddei, "The Natural Radioactivity of Brazilian Phosphogypsum," Journal of Radioanalytical and Nuclear Chemistry, Vol. 249, No. 1, 2001, pp. 251-255. doi:10.1023/A:1013215215484

[8] A. El-Taher and S. S. Althoyaib, "Natural Radioactivity Levels and Heavy Metals in Chemical and Organic Fertilizers Used in Kingdom of Saudi Arabia," Applied Radiation and Isotopes, Vol. 70, No. 1, 2012, pp. 290-295. doi:10.1016/j.apradiso.2011.08.010

[9] M. Gascoyne, "Geochemistry of the Actinides and Their Daughters," In: M. Ivanovich and R. S. Harmon, Eds., Uranium Series Disequilibrium Applications to Earth, Marine and Environmental Science, Clarnandon Press, Oxford, 1992.

[10] B. Y. Lalit and T. V. Ramachandran, "Natural Radiation Environment," 3rd Edition, Department of Energy, 1980, p. 800 .

[11] N. Ibrahim, "Determination of Natural Radioactivity in Fertilizers Using Gamma Ray," Spectroscopy Journal of Nuclear Physics and Chemistry, Vol. 51, No. 46, 1998, p. 621.

[12] A. G. E. Abbady, "Estimation of Radiation Hazard Indices from Sedimentary Rocks in Upper Egypt," Applied Radiation and Isotopes, Vol. 60, No. 1, 2004, pp. 111114. doi:10.1016/j.apradiso.2003.09.012

[13] I. Beretka and P. I. Mathew, "Natural Radioactivity of Australian Building Materials, Waste and By-Products," Health Physics, Vol. 48, No. 1, 1985, pp. 87-95. doi:10.1097/00004032-198501000-00007

[14] UNSCEAR, "United Nations Science Committee on the Effects of Atomic Radiation Report to the General Assembly, with Scientific Annexes," United Nations, New York, 2000

[15] UNSCEAR, "United Nations Scientific Committee on the
Effect of Atomic Radiation, Report to the General Assembly," United Nations, New York, 1993.

[16] UNSCEAR, "Sources, Effects and Risks of Ionizing Radiation," United Nations, New York, 1988.

[17] ICRP, "International Commission on Radiological Protection, the 1990-1991 Recommendations of the International Commission on Radiological Protection, Publication 60," Pergamon, Oxford, 1991.

[18] N. K. Ahmed and A. M. El-Arabi, "Natural Radioactivity in Farm Soil and Phosphate Fertilizer and Its Environmental Implication in Qena Governorate, Upper Egypt," Journal of Environmental Radioactivity, Vol. 84, No. 1, 2005, pp. 51-64. doi:10.1016/j.jenvrad.2005.04.007

[19] P. Chauhn, R. P. Chauhan and M. Gupta, "Estimation of naturally Occurring in Radionuclides Fertilizers Using Gamma Spectrometry and Elemental by XRF and XRD Techniques," Microchemical Journal, 2012, in Press.

[20] K. Khan, H. M. Khan, M. Tufail and N. Shmsf, "Gamma Spectrometric Studies of Single Super Phosphate Fertilizer Samples," In: Proceedings of National Seminar on Occupational Safety in Mining \& Industries, Peshawar, 1996.

[21] N. N. Jibiril and K. P. Fasae, "Activity Concentrations of ${ }^{226} \mathrm{Ra},{ }^{232} \mathrm{Th}$ and ${ }^{40} \mathrm{~K}$ in Brands of Fertilizer Used in Nigeria, Radiation Protection Dosimetry," Vol. 148, No. 1, 2012, pp. 132-137.

[22] C. H. Saueia, B. P. Mazzilli and D. I. T. Favaro, "Natural Radioactivity in Posphogypsum and Fertilizer in Brazil," Journal of Radioanalytical and Nuclear Chemictry, Vol. 264, No. 2, 2005, pp. 445-448. doi:10.1007/s10967-005-0735-4

[23] R. Mustonen, "Radioactivity of Fertilizer in Finland," Science of the Total Environment, Vol. 45, 1985, pp. 127134. doi:10.1016/0048-9697(85)90212-8

[24] R. J. Gulmond and S. T. Windham, "Radionuclide's in the Environment," Technical Note No. ORP/CSD-75-3, USEPA, 1975, pp. 228-229. 